Contents lists available at \ournal IICET

JPPI (Jurnal Penelitian Pendidikan Indonesia)

ISSN: 2502-8103 (Print) ISSN: 2477-8524 (Electronic)

\title{
The role of transformational leadership, leader member exchange, digital transformation on organizational citizenship behaviour and work innovation capabilities in during Covid-19 pandemic
}

\author{
Calen Calen $^{1}$, Sri Aprianti Tarigan ${ }^{2 *}$, Rosita Rosita ${ }^{2}$, Susanto Susanto ${ }^{2}$, Erina Alimin $^{3}$ \\ ${ }^{1}$ Sekolah Tinggi Akuntansi dan Manajemen Indonesia, Indonesia \\ ${ }^{2}$ Institut Bisnis InformasiTeknologi dan Bisnis, Medan, Indonesia \\ ${ }^{3}$ Universitas Pelita Harapan, Medan, Indonesia
}

\section{Article Info}

\section{Article history:}

Received Jun $18^{\text {th }}, 2021$

Revised Jul $06^{\text {th }}, 2021$

Accepted Aug 24 $4^{\text {th }}, 2021$

\section{Keyword:}

Transformational leadership Leader member exchange Digital transformation

Work innovation capabilities Organizational citizenship Behavior

\begin{abstract}
The purpose of this study is to analyze the relationship between Transformational Leadership, Leader Member Exchange, Digital Transformation on Work Innovation Capabilities and Organizational Citizenship Behavior. In this study using quantitative methods and data analysis techniques Structural Equation Modeling (SEM) using SmartPLS 3.0 software. This research was conducted the sample units were 390 Micro, Small \& Medium Enterprises (MSMEs). Based on the results of data analysis, it is concluded that transformational leadership has a significant effect on Work Innovation Capabilities, transformational leadership has no significant effect on Organizational Citizenship Behavior, Leader Member Exchange has a significant effect on Work Innovation Capabilities, Leader Member Exchange has no significant effect on Organizational Citizenship Behavior, digital transformation has no significant effect on Work Innovation Capabilities, digital Transformation has no significant effect on Organizational Citizenship Behavior, Work Innovation Capabilities have no significant effect on Organizational Citizenship Behavior, transformational Leadership has no significant effect on Work Innovation Capabilities through Organizational Citizenship Behavior, Leader Member Exchange has no significant effect on Work Innovation Capabilities via Organizational Citizens hip Behavior , digital transformation has no significant effect on Work Innovation Capabilities through Organizational Citizenship Behavior.
\end{abstract}

(C) 2021 The Authors. Published by IICET

This is an open access article under the CC BY-NC-SA license (https://creativecommons.org/licenses/by-nc-sa/4.0)

\section{Corresponding Author:}

Sri Aprianti Tarigan,

Institut Bisnis InformasiTeknologi dan Bisnis, Medan

Email: sriapriantitarigan@gmail.com

\section{Introduction}

The Covid-19 pandemic has had a negative impact on the sustainability of Indonesia's economic life, especially for SMEs. Thaha's research (2020) reported that 163,713 MSME actors in the food and beverage sector were affected by the Covid-19 pandemic. The results of the research report were added to the data from the Kemenkop MSMEs which reported that 56\% of MSME actors experienced a decline in sales, $22 \%$ in the financing aspect, $15 \%$ in the aspect of goods distribution, and $4 \%$ had difficulty getting raw materials. namely 
$38 \%$ do marketing through social media, $35 \%$ use paid promotions that are already available online, $13 \%$ leave products conventionally and 6\% keep their places of sale open. According to Wijaya et al (2020), Lusiani et al. (2020) provides an overview of the obstacles and opportunities for problem solving for MSME actors in a pandemic situation. The existence of a policy of social distancing and staying at home makes the conventional market empty of enthusiasts, resulting in an increase in the digital market. This opportunity is used by MSME actors to market their products through the digital market. The strategy of MSME actors in dealing with the Covid-19 pandemic situation can allegedly be done through online product marketing. The obstacle to this strategy is that MSME actors do not understand how to market products digitally, from photography, advertising design, to product publication on digital platforms. The impact of this strategy resulted in tremendous savings in the conventional production, distribution and marketing sectors. The online marketing process allows the production of MSME actors to be only order-oriented, thereby reducing the number of workers needed during the production to distribution process. In addition, the online market loosens up MSME players in opening marketing places, so they are not burdened with space rent. Research According to Affandi et al. (2020) shows the MSME survival strategy in the midst of the Covid-19 Pandemic which includes recommendations for conducting e-commerce trade, doing digital marketing, improving product quality, adding customer service, and optimizing customer marketing relationships.

In Indonesia, almost all sectors are affected, especially the economic ecosystem which has been the focus of society. Furthermore, the Covid-19 pandemic has caused a slowdown in the economic sector in Indonesia with its various derivatives. The Micro, Small and Medium Enterprises (MSME) sector, which is the most important part of the economic sector, is greatly affected. This is what is worried by all parties, because it has made the MSME sector experience a significant setback. Moreover, currently many MSMEs are experiencing various problems such as declining sales, capital, hampered distribution, difficulty in raw materials. decreased production and the occurrence of many layoffs for workers and labor which later became a threat to the national economy. MSMEs as drivers of the domestic economy and absorber of labor are facing a decline in productivity which results in a significant decrease in profit. According to Purwanto et al. (2021), Nugroho et al. (2020), Wijaya et al (2020), Lusiani et al. (2020) The impact is that many MSMEs have to close their businesses due to declining purchases and are still dependent on offline sales. So that some MSME sectors that have not adapted digitally are ultimately very affected and closed their outlets. Even so, the Covid-19 pandemic has indirectly prompted new changes in Indonesia's business style. The change is the shift from offline business to digital business which is also known as the phenomenon of digital entrepreneurship. Social media and market places (intermediaries) can be a concept to make it easier for MSME actors to get wider marketing access (Purnomo, 2019). It should be noted that MSMEs in Indonesia have become the most important pillars for the economic ecosystem. Moreover, it is known that $99 \%$ of business actors in Indonesia are the MSME sector. The role of MSMEs has contributed $60 \%$ to the national gross domestic product and $97 \%$ to the absorption of workers affected by the pandemic. Meanwhile, only 16 percent of the existing MSMEs have entered the digital economy ecosystem. In the context of Indonesia, the MSME sector is one of the main pillars of Indonesia's economic fundamentals. According to Affandi et al.(2020) the role of digital technology has a significant influence on the new business units created. Emerging technology paradigms harness the potential for collaboration and collective intelligence to design and launch more robust and sustainable entrepreneurial initiatives.

According to Yunus (2015), Purwanto et al. (2021), Nugroho et al. (2020) during the Covid 19 pandemic, the use of digital platforms by MSME actors in Indonesia has increased quite a bit. There are 42 percent of Indonesian MSMEs that already use social media. In other words, social media is a means of developing entrepreneurship and the sustainability of SMEs (Purwanto, et al, 2017). Meanwhile, based on McKinsey data, e-commerce sales have increased by 26 percent with a total of 3.1 million transactions per day (Kompas.com, 2020). Even during the Covid-19 pandemic, it has encouraged higher use of social media which of course correlates to the increase in sales transactions for MSMEs. In other words, MSME actors who have succeeded in conducting sales transactions during this pandemic are those who have succeeded in utilizing digital platforms and social media. In addition, the development of the digitization of MSMEs will make the digital economy in Indonesia by 2025 the largest in Southeast Asia.

\section{Hypotheses Development}

\section{Relationship between Transformational Leadership and Work Innovation Capabilities}

Transformational Leadership Theory by Adwan et al. (2019) stated that Transformational Leadership will have a positive influence on increasing Work Innovation Capabilities. According to research conducted by Nugroho et al. (2020), Wijaya et al (2020), Lusiani et al. (2020)) states that an increase in Transformational Leadership will encourage an increase in the Work Innovation Capabilities variable. While the research conducted by Purwanto et al. (2021) states that an increase in the Transformational Leadership variable will encourage an increase in the Work Innovation Capabilities variable. According to research conducted by 
Fayaz (2017), Quddus (2020) states that Transformational Leadership has a significant influence on the Work Innovation Capabilities variable. Based on theoretical studies and previous studies, the following hypotheses are formulated:

Hypothesis 1: There is a positive influence between Transformational Leadership and Work Innovation Capabilities

\section{Relationship between Transformational Leadership and Organizational Citizenship Behavior}

Transformational Leadership Theory by Adwan et al. (2019) stated that Transformational Leadership will have a positive influence on improving Organizational Citizenship Behavior. According to research conducted by Cheng et al. (2013), Christopher (2021), El-Gohary (2013) stated that an increase in Transformational Leadership will encourage an increase in the Organizational Citizenship Behavior variable. While the research conducted by Purwanto et al. (2021) states that an increase in the Transformational Leadership variable will encourage an increase in the variable Organizational Citizenship Behavior. According to research conducted by Adwan et al. (2019); Bazazo et al. (2017) and Bui et al. (2006) stated that Transformational Leadership has a significant influence on the variable Organizational Citizenship Behavior. Based on theoretical studies and previous studies, the following hypotheses are formulated:

Hypothesis 2: There is a positive influence between Transformational Leadership and Organizational Citizenship Behavior

\section{Relationship between Leader Member Exchange and Work Innovation Capabilities}

The Leader Member Exchange Theory by Adwan et al. (2019) stated that the Leader Member Exchange will have a positive influence on increasing Work Innovation Capabilities. According to research conducted by Zhou et al. (2021), Yunus (2015) stated that an increase in the Leader Member Exchange will encourage an increase in the Work Innovation Capabilities variable. While the research conducted by Purwanto et al. (2021) states that an increase in the Leader Member Exchange variable will encourage an increase in the Work Innovation Capabilities variable. According to research conducted by Fayaz (2017), Quddus (2020) states that Leader Member Exchange has a significant influence on the Work Innovation Capabilities variable. Based on theoretical studies and previous studies, the following hypotheses are formulated:

Hypothesis 3: There is a positive influence between Leader Member Exchange and Work Innovation Capabilities

\section{Relationship between Leader Member Exchange and Organizational Citizenship Behavior}

The Leader Member Exchange Theory by Adwan et al. (2019) stated that the Leader Member Exchange will have a positive influence on increasing Organizational Citizenship Behavior. According to research conducted by Burawat (2019), Gui (2021), Hernández (2020) stated that an increase in the Leader Member Exchange will encourage an increase in the Organizational Citizenship Behavior variable. Meanwhile, the research conducted by Purwanto et al. (2021) states that an increase in the Leader Member Exchange variable will encourage an increase in the Organizational Citizenship Behavior variable. According to research conducted by El Toufaili (2017), Fayaz (2017), Quddus (2020) states that Leader Member Exchange has a significant influence on the Organizational Citizenship Behavior variable. Based on theoretical studies and previous studies, the following hypotheses are formulated:

Hypothesis 4: There is a positive influence between Leader Member Exchange and Organizational Citizenship Behavior

\section{Relationship between Digital Transformation and Work Innovation Capabilities}

Digital Transformation Theory by Adwan et al. (2019) stated that Digital Transformation will have a positive influence on increasing Work Innovation Capabilities. According to research conducted by Yunus (2015), Purwanto et al. (2021), Nugroho et al. (2020), Wijaya et al (2020), Lusiani et al. (2020) stated that an increase in Digital Transformation would encourage an increase in the Work Innovation Capabilities variable. While the research conducted by Purwanto et al. (2021) stated that an increase in the Digital Transformation variable would encourage an increase in the Work Innovation Capabilities variable. According to research conducted by Adwan et al. (2019); Bazazo et al. (2017) and Bui et al. (2006) stated that Digital Transformation has a significant effect on the Work Innovation Capabilities variable. Based on theoretical studies and previous studies, the following hypotheses are formulated:

Hypothesis 5: There is a positive influence between Digital Transformation and Work Innovation Capabilities

Relationship between Digital Transformation and Organizational Citizenship Behavior

Digital Transformation Theory by Adwan et al. (2019) states that Digital Transformation will have a positive effect on increasing Organizational Citizenship Behavior. According to research conducted by E1 Toufaili 
(2017), Fayaz (2017), Quddus (2020) states that increasing Digital Transformation will encourage an increase in Organizational Citizenship Behavior variables. Meanwhile, the research conducted by Purwanto et al. (2021) stated that an increase in the Digital Transformation variable will encourage an increase in the Organizational Citizenship Behavior variable. According to research conducted by Adwan et al. (2019); Bazazo et al. (2017) and Bui et al. (2006) stated that Digital Transformation has a significant influence on the variable Organizational Citizenship Behavior. Based on theoretical studies and previous studies, the following hypotheses are formulated:

Hypothesis 6: There is a positive influence between Digital Transformation and Organizational Citizenship Behavior

\title{
Relationship between Work Innovation Capabilities and Organizational Citizenship Behavior
}

Theory of Work Innovation Capabilities by Adwan et al. (2019) stated that Work Innovation Capabilities will have a positive influence on improving Organizational Citizenship Behavior. According to research conducted by Wijaya et al (2020), Lusiani et al. (2020) stated that an increase in Work Innovation Capabilities would encourage an increase in the Organizational Citizenship Behavior variable. Meanwhile, the research conducted by Purwanto et al. (2021) stated that an increase in the Work Innovation Capabilities variable would encourage an increase in the Organizational Citizenship Behavior variable. According to research conducted by Adwan et al. (2019); Bazazo et al. (2017) and Bui et al. (2006) stated that Work Innovation Capabilities have a significant effect on the variable Organizational Citizenship Behavior. Based on theoretical studies and previous studies, the following hypotheses are formulated:

Hypothesis 7: There is a positive influence between Work Innovation Capabilities and Organizational Citizenship Behavior

\begin{abstract}
Relationship between Transformational Leadership and Work Innovation Capabilities through Organizational Citizenship Behavior

Transformational Leadership Theory by Adwan et al. (2019) states that Transformational Leadership will have a positive influence on increasing Organizational Citizenship Behavior through Work Innovation Capabilities. According to research conducted by According to Wijaya et al (2020), Lusiani et al. (2020) stated that an increase in Transformational Leadership will encourage an increase in the Organizational Citizenship Behavior variable through Work Innovation Capabilities. While the research conducted by Purwanto et al. (2021) states that an increase in the Transformational Leadership variable will encourage an increase in the Organizational Citizenship Behavior variable through Work Innovation Capabilities. According to research conducted by Adwan et al. (2019); Bazazo et al. (2017) and Bui et al. (2006) stated that Transformational Leadership has a significant influence on the variable Organizational Citizenship Behavior through Work Innovation Capabilities. Based on theoretical studies and previous studies, the following hypotheses are formulated:
\end{abstract}

Hypothesis 8 : There is a positive influence between Transformational Leadership and Work Innovation Capabilities through Organizational Citizenship Behavior

The relationship between Leader Member Exchange and Work Innovation Capabilities through Organizational Citizenship Behavior Transformational Leadership Theory by Adwan et al. (2019) states that the Leader Member Exchange will have a positive influence on increasing Organizational Citizenship Behavior through Work Innovation Capabilities. According to research conducted by Fayaz (2017), Quddus (2020) states that increasing the Leader Member Exchange will encourage an increase in the variable Organizational Citizenship Behavior through Work Innovation Capabilities. Meanwhile, the research conducted by Purwanto et al. (2021) states that an increase in the Leader Member Exchange variable will encourage an increase in the Organizational Citizenship Behavior variable through Work Innovation Capabilities. According to research conducted by Gandolfi (2018), Burawat (2019), Gui (2021) states that the Leader Member Exchange has a significant influence on the Organizational Citizenship Behavior variable through Work Innovation Capabilities. Based on theoretical studies and previous studies, the following hypotheses are formulated:

Hypothesis 9 : There is a positive influence between Leader Member Exchange and Work Innovation Capabilities through Organizational Citizenship Behavior

\section{Relationship between Digital Transformation and Work Innovation Capabilities through Organizational Citizenship} Behavior

Digital Transformation Theory by Adwan et al. (2019) states that Digital Transformation will have a positive influence on improving Organizational Citizenship Behavior through Work Innovation Capabilities. According to research conducted by Yunus (2015), Purwanto et al. (2021), Nugroho et al. (2020), Wijaya et al 
(2020), Lusiani et al. (2020)) stated that an increase in Digital Transformation will encourage an increase in the Organizational Citizenship Behavior variable through Work Innovation Capabilities. Meanwhile, the research conducted by Purwanto et al. (2021) states that an increase in the Digital Transformation variable will encourage an increase in the Organizational Citizenship Behavior variable through Work Innovation Capabilities. . According to research conducted by Maroukian (2020), Gandolfi (2018) states that Digital Transformation has a significant influence on the variable Organizational Citizenship Behavior through Work Innovation Capabilities. Based on theoretical studies and previous studies, the following hypotheses are formulated:

Hypothesis 10: There is a positive influence between Digital Transformation and Work Innovation Capabilities through Organizational Citizenship Behavior

\section{Method}

In this study using quantitative methods and data analysis techniques Structural Equation Modeling Equation Modeling using SmartPLS 3.0 software. This research was conducted in the population in this study were all MSMEs in Tangerang City as many as 41,155 MSMEs and based on the method of determining the number of samples according to Morgan, the sample units were 380 MSMEs. While the sample selection method uses non-probability sampling methods. Data collection in this study was carried out using techniques and procedures, namely online questionnaires. Questionnaire is the main instrument in collecting primary data. After the questionnaires were sent to the respondents as many as 450 questionnaires, the next step was to evaluate the returned questionnaires, namely 390 returned questionnaires and 60 questionnaires did not return.

\section{Research Model}

Based on theoretical studies and previous studies, the research model is structured as follows

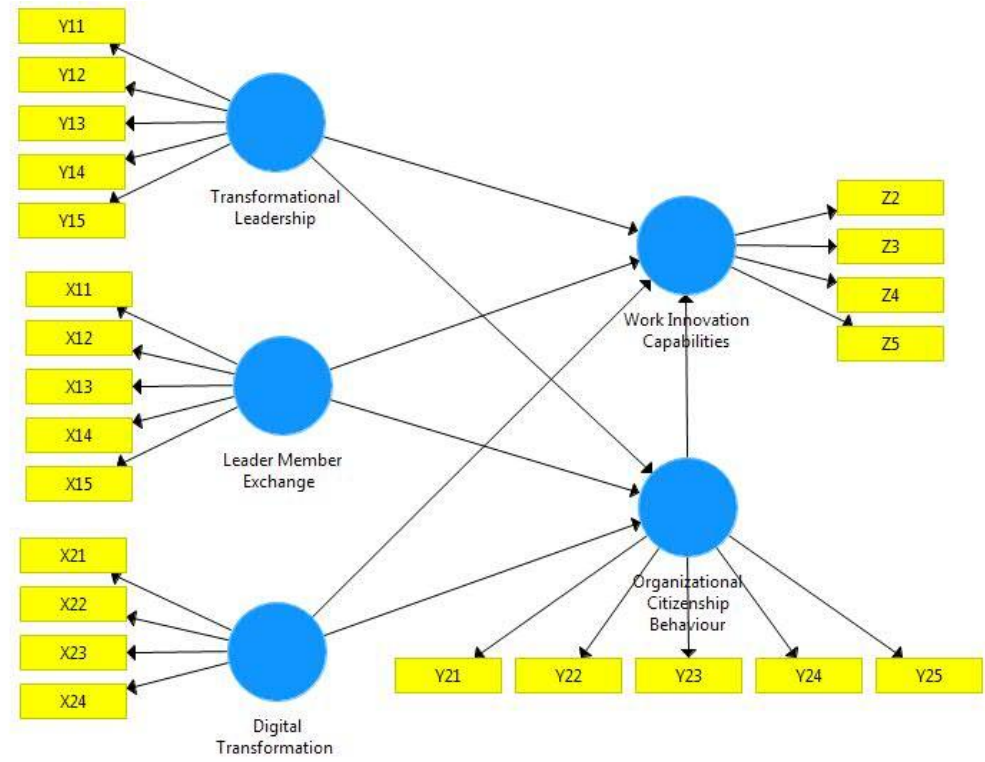

Figure 1. Research Model

In this study there are 10 hypotheses as follows:

Hypothesis 1: There is a positive influence between Transformational Leadership and Work Innovation Capabilities

Hypothesis 2: There is a positive influence between Transformational Leadership and Organizational Citizenship Behavior

Hypothesis 3: There is a positive influence between Leader Member Exchange and Work Innovation Capabilities

Hypothesis 4: There is a positive influence between Leader Member Exchange and Organizational Citizenship Behavior

Hypothesis 5: There is a positive influence between Digital Transformation and Work Innovation Capabilities 
Hypothesis 6: There is a positive influence between Digital Transformation and Organizational Citizenship Behavior

Hypothesis 7: There is a positive influence between Work Innovation Capabilities and Organizational Citizenship Behavior

Hypothesis 8 : There is a positive influence between Transformational Leadership and Work Innovation Capabilities through Organizational Citizenship Behavior

Hypothesis 9: There is a positive influence between Leader Member Exchange and Work Innovation Capabilities through Organizational Citizenship Behavior

Hypothesis 10: There is a positive influence between Digital Transformation and Work Innovation Capabilities through Organizational Citizenship Behavior

\section{Data Processing Stages \\ Reliability Test}

According to Purwanto et al (2021) reliability is a measure of the internal consistency of indicators of a construct that shows the degree to which each indicator shows a general latent construct. According to Purwanto et al (2020) the reliability requirement is a measure of the stability and consistency of the results (data) at different times. To test the reliability of the construct in this study used the value of composite reliability. A variable is said to meet construct reliability if it has a composite reliability value $>0.7$ and Cronbach's Alpha value $>0.7$ has a good level of reliability for a variable (Purwanto et al, 2019).

\section{Validity Test}

After the data test results are declared reliable, then the next step is to test the validity including loading factor, AVE, Farnell Lacker Criterion and cross loading. The steps that need to be taken are selecting the outer loading menu to see the results of the loading factor test, then the discriminant validity menu to see the results of the Farnell lacker criterion and cross loading tests. . According to Purwanto et al. (2020) The validity test is intended to measure the extent to which the accuracy and accuracy of a measuring instrument performs the function of its measuring instrument or provides appropriate measurement results by calculating the correlation between each statement with a total score. In this study, the measurement validity test consisted of convergent validity and discriminant validity.

\section{Convergent Validity}

Convergent validity is used to measure the correlation between item scores and construct scores, the higher the correlation the better the data validity (Purwanto, 2019). Measurement Measurement can be categorized as having convergent validity if the loading factor value is $>0.7$ (Purwanto et al, 2021). If all loading factors have a value of $>0.7$, it can be concluded that all indicators have met the criteria for convergent validity, because no indicators for all variables have been eliminated from the model.

\section{Discriminant validity}

Discriminant validity is a test of construct validity by predicting the size of the indicator from each block (Purwanto et al, 2019). One of the discriminant validity can be seen by comparing the AVE value with the correlation between other constructs in the model. If the AVE root value is $>0.50$, it means that discriminant validity is reached (Purwanto et al, 2020). In addition, discriminant validity is also carried out based on the FornellLarcker criteria measurement with constructs. In addition to using the AVE value, another method that can be used to determine discriminant validity is to measure discriminant validity by using the cross loading value. An indicator is said to meet discriminant validity if the cross loading value is 0.70 or more (Purwanto, 2020).

\section{Structural model (inner model)}

The structural model (inner model) is a pattern of research variable relationships. Evaluation of the structural model is by looking at the coefficients between variables and the value of the coefficient of determination (R2). The coefficient of determination (R2) essentially measures how far the model's ability to explain variations in the dependent variable is. A value close to 1 means that the independent variables provide almost all the information needed to predict the variation of the dependent variable (Purwanto, 2021). This test aims to determine how much the independent variable model's ability to explain the dependent variable. The value of $\mathrm{R}$ square (R2) is a measure of the proportion of the variation in the value of the affected variable which can be explained by the variable that influences it. According to Purwanto et al (2020) if in a study using more than two independent variables, then the adjusted r-square (adjusted R2) is used. The value of $r$ square adjusted is a value that is always smaller than $\mathrm{r}$ square. The $\mathrm{R} 2$ value is close to 1 , with the limiting criteria being divided into 3 classifications, namely:

If the value of $\mathrm{R} 2=0.67 \mathrm{Model}$ is substance (strong)

If the value of $\mathrm{R} 2=0.33$ the model is moderate (medium) 
If the value of $\mathrm{R} 2=0.19$ the model is weak (bad)

In this study, the adjusted r-square value (adjusted R2) is used, because it has more than two independent variables.

\section{Hypothesis Testing}

According to Purwanto et al (2021) After a research model is believed to be fit, a hypothesis test can be performed. The next step is to test the hypothesis that has been built in this study. In this case, the bootstrapping method is applied to the sample. Testing with bootstrapping is intended to minimize the problem of abnormal research data. The last step of the test using the smart Pls application is hypothesis testing and is carried out by looking at the results of the bootstrapping value. This test is done by selecting the calculate menu and after that the menu options appear, then select bootstrapping, then the desired data will appear. The following are the results of the data test using bootstrapping. Hypothesis testing in this study can be known through regression weight by comparing the p-value with a significance level of $5 \%(\alpha=5 \%)$. The hypothesis is said to be significant if it has a probability value ( $\mathrm{p}$-value $)<5 \%$.

\section{Results and Discussions}

\section{Reliability Test}

According to Purwanto et al (2021) reliability is a measure of the internal consistency of indicators of a construct that shows the degree to which each indicator shows a general latent construct. According to Purwanto et al (2020) the reliability requirement is a measure of the stability and consistency of the results (data) at different times. To test the reliability of the construct in this study used the value of composite reliability. A variable is said to meet construct reliability if it has a composite reliability value $>0.7$ and Cronbach's Alpha value $>0.6$ has a good level of reliability for a variable (Purwanto et al, 2019). The composite reliability value of each indicator can be seen in table 1 below

Tabel 1. Reliability

\begin{tabular}{lll}
\hline Variables & Cronbach's Alpha & Composite Reliability \\
\hline Transformational Leadership & 0.926 & 0.939 \\
\hline Leader Member Exchange & 0.933 & 0.948 \\
\hline Digital Transformation & 0.995 & 0.986 \\
\hline Work Innovation Capabilities & 0.981 & 0.986 \\
\hline $\begin{array}{l}\text { Organizational Citizenship } \\
\text { Behaviour }\end{array}$ & 0.976 & 0.982 \\
\hline
\end{tabular}

In table 1 , it can be seen the results of the analysis of the reliability test using the SmartPLS tool which states that all composite reliability values are each greater than 0.7 , which means that all variables are reliable and have met the test criteria. Furthermore, the value of cronbanch's omission also shows that all cronbanch's 'alpa' values are more than 0.6 and this indicates the level of reliability of the variable has also met the criteria.

\section{Validity test}

After the data test results are declared reliable, then the next step is to test the validity including loading factor, AVE, Farnell Lacker Criterion and cross loading. The steps that need to be taken are selecting the outer loading menu to see the results of the loading factor test, then the discriminant validity menu to see the results of the Farnell lacker criterion and cross loading tests. According to Purwanto et al. (2020) The validity test is intended to measure the extent to which the accuracy and accuracy of a measuring instrument performs the function of its measuring instrument or provides appropriate measurement results by calculating the correlation between each statement with a total score. In this study, the measurement validity test consisted of convergent validity and discriminant validity.

\section{Convergent Validity}

Convergent validity is used to measure the correlation between item scores and construct scores, the higher the correlation the better the data validity (Purwanto, 2019). Measurement Measurement can be categorized as having convergent validity if the loading factor value is $>0.7$ (Purwanto et al, 2021). Figure 2 shows that all loading factors have a value $>0.7$, so it can be concluded that all indicators have met the criteria for convergent validity, because indicators for all variables have not been eliminated from the model. 


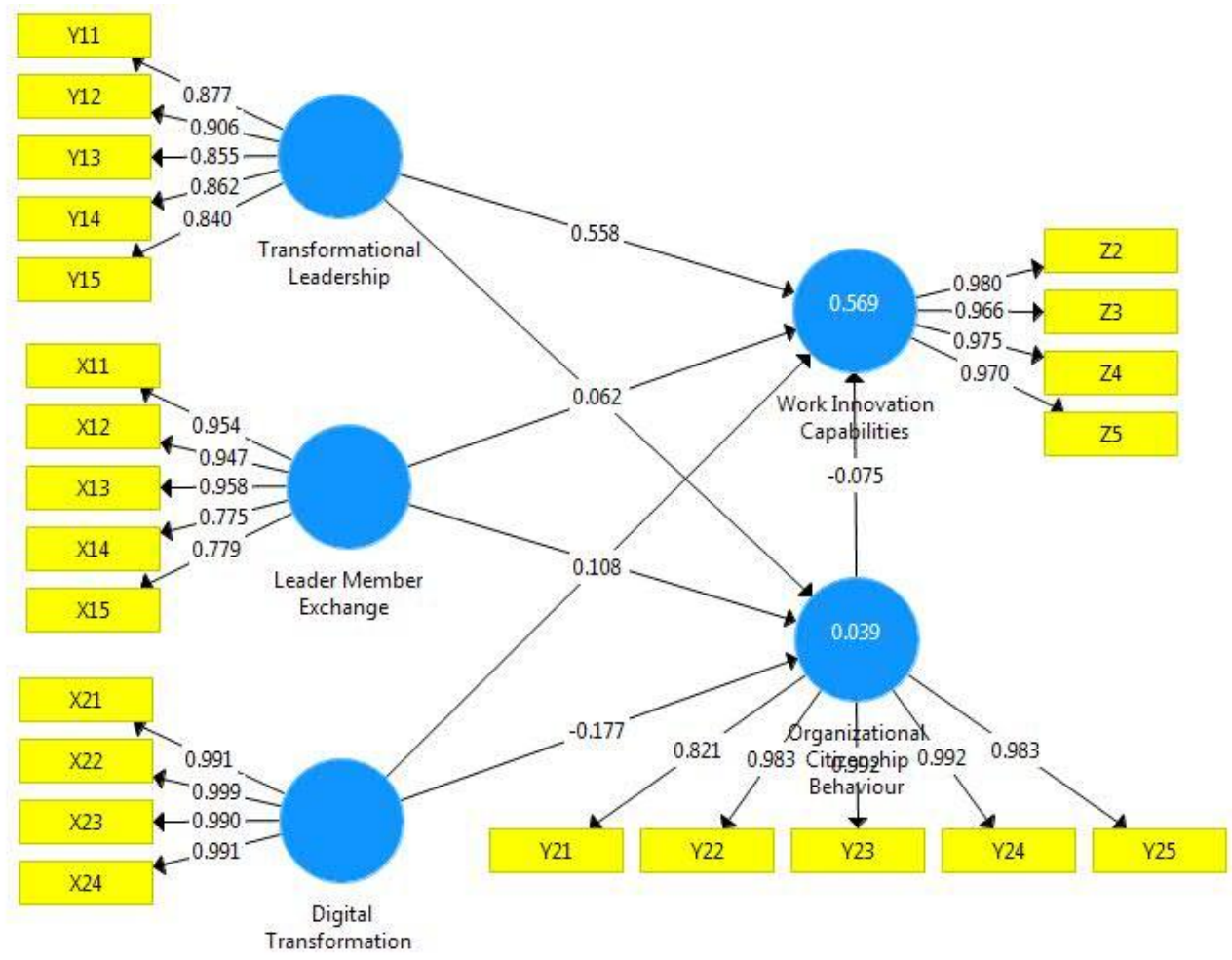

Figure 2. Convergen Validity

\section{Discriminant validity}

Discriminant validity is a test of construct validity by predicting the size of the indicator from each block (Purwanto et al, 2019). One of the discriminant validity can be seen by comparing the AVE value with the correlation between other constructs in the model. If the AVE root value is $>0.50$, it means that discriminant validity is reached (Purwanto et al, 2020).

Based on table 2, the AVE value for all variables is $>0.50$. So it can be said that the measurement model has been valid with discriminant validity. In addition, discriminant validity was also carried out based on the FornellLarcker criteria measurement with the construct. If the construct correlation in each indicator is greater than the other constructs, it means that latent constructs can predict indicators better than other constructs (Purwanto et al, 2019).

Table 2. AVE

\begin{tabular}{ll}
\hline Variables & AVE \\
\hline Transformational Leadership & 0.754 \\
\hline Leader Member Exchange & 0.786 \\
\hline Digital Transformation & 0.985 \\
\hline Work Innovation Capabilities & 0.946 \\
\hline Organizational Citizenship Behaviour & 0.915 \\
\hline
\end{tabular}

\section{Structural model (inner model)}

The structural model (inner model) is a pattern of research variable relationships. Evaluation of the structural model is by looking at the coefficients between variables and the value of the coefficient of determination (R2). The coefficient of determination (R2) essentially measures how far the model's ability to explain variations in the dependent variable is. A value close to 1 means that the independent variables provide almost all the information needed to predict the variation of the dependent variable (Purwanto, 2021). This test aims to determine how much the independent variable model's ability to explain the dependent variable. The value of $\mathrm{R}$ square (R2) is a measure of the proportion of the variation in the value of the affected variable which can be explained by the variable that influences it. According to Purwanto et al (2020) if in a study using more than two independent variables, then the adjusted r-square (adjusted R2) is used. The value of $r$ square adjusted is a value that is always smaller than $\mathrm{r}$ square. The $\mathrm{R} 2$ value is close to 1 , with the limiting criteria being divided into 3 classifications, namely: 
If the value of $\mathrm{R} 2=0.67$ Model is substance (strong)

If the value of $\mathrm{R} 2=0.33$ the model is moderate (medium)

If the value of $\mathrm{R} 2=0.19$ the model is weak (bad)

In this study, the adjusted r-square value (adjusted R2) is used, because it has more than two independent variables.

Tabel 3 . r-square adjusted

\begin{tabular}{ll}
\hline Variables & r-square adjusted \\
\hline Work Innovation Capabilities & 0.569 \\
\hline Organizational Citizenship Behaviour & 0.039 \\
\hline
\end{tabular}

In table 3 it can be explained that: 1) The adjusted R2 value of the independent variables of Transformational Leadership, Leader Member Exchange, Digital Transformation on the dependent variable of Work Innovation Capabilities is $0.569 ; 2$ ) This value is categorized as moderate, so it can be concluded that the two independent variables have a moderate influence and level on the dependent variable; 3) The independent variables Transformational Leadership, Leader Member Exchange, Digital Transformation contribute to the dependent variable Work Innovation Capabilities by $56.9 \%$ while the remaining $43.1 \%$ is influenced by other variables not discussed in this study; 4) The adjusted R2 value of the independent variables Transformational Leadership, Leader Member Exchange, Digital Transformation, Work Innovation Capabilities on the dependent variable work innovation behavior 0.039 ; 5) This value is categorized as weak, so it can be concluded that the two independent variables have a bad influence on the dependent variable. 5) The independent variables of Transformational Leadership, Leader Member Exchange, Digital Transformation, Work Innovation Capabilities on the dependent variable of work innovation behavior are 3.9\%while the remaining $96.1 \%$ is influenced by other variables not discussed in this study

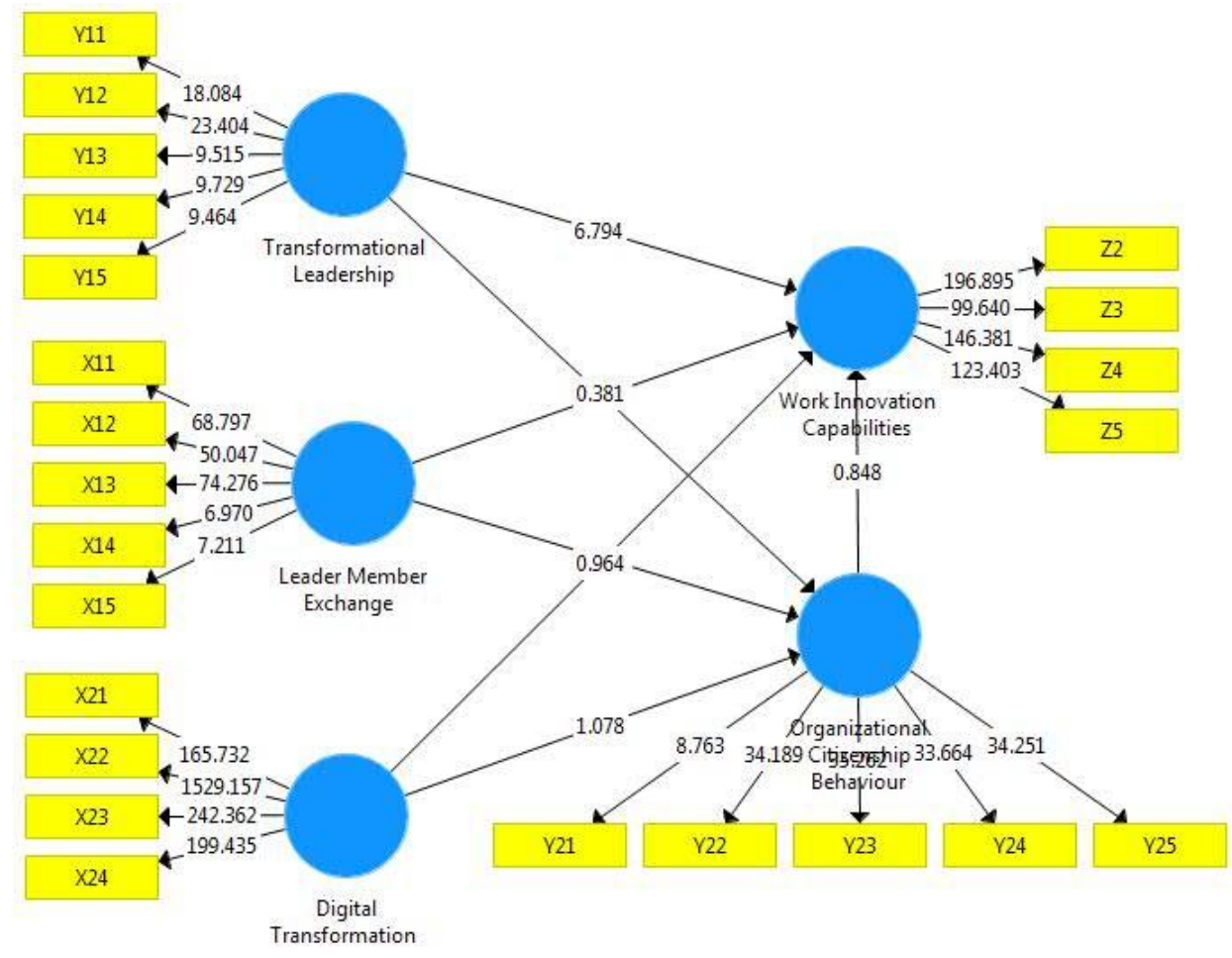

Figure 3. Hypotheses Testing

\section{Hypothesis test}

According to Purwanto et al (2021) After a research model is believed to be fit, a hypothesis test can be performed. The next step is to test the hypothesis that has been built in this study. The following are the results of the data test using bootstrapping. Hypothesis testing in this study can be known through regression weight by comparing the $p$-value with a significance level of $5 \%(\alpha=5 \%)$. The hypothesis is said to be significant if it has a probability value ( $p$-value) $<5 \%$. 
Table 4. Hypotheses Testing for Direct Effect

\begin{tabular}{lll}
\hline Hypotheses & P - Value & Result \\
\hline $\begin{array}{l}\text { Transformational Leadership ->Work Innovation } \\
\text { Capabilities }\end{array}$ & 0.000 & Significant \\
\hline $\begin{array}{l}\text { Transformational Leadership->Organizational } \\
\text { Citizenship Behaviour }\end{array}$ & 0.703 & Not Significant \\
\hline $\begin{array}{l}\text { Leader Member Exchange->Work Innovation } \\
\text { Capabilities }\end{array}$ & 0.002 & Significant \\
\hline $\begin{array}{l}\text { Leader Member Exchange->Organizational } \\
\text { Citizenship Behaviour }\end{array}$ & 0.317 & Not Significant \\
\hline $\begin{array}{l}\text { DigitalTransformation ->Work Innovation } \\
\text { Capabilities }\end{array}$ & 0.335 & Not Significant \\
\hline $\begin{array}{l}\text { Digital Transformation->Organizational } \\
\text { Citizenship Behaviour }\end{array}$ & 0.381 & Not Significant \\
\hline $\begin{array}{l}\text { Work Innovation Capabilities ->Organizational } \\
\text { Citizenship Behaviour }\end{array}$ & 0.397 & Not Significant \\
\hline
\end{tabular}

\section{Relationship between Transformational Leadership and Work Innovation Capabilities}

Based on the results of data analysis using SmartPLS obtained p value $0.000<0.050$ so it can be concluded that Transformational Leadership has a significant effect on Work Innovation Capabilities, an increase in the transformational leadership variable will have a significant effect on increasing the Work Innovation Capabilities variable and a decrease in the Transformational Leadership variable will have a significant effect on decreasing variable Work Innovation Capabilities. This result is not in line with the research conducted by Nugroho et al. (2020), Wijaya et al (2020), Lusiani et al. (2020) that Transformational Leadership has a positive and significant effect on Work Innovation Capabilities.

\section{Relationship between Transformational Leadership and Organizational Citizenship Behavior}

Based on the results of data analysis using SmartPLS, the p value is $0.703<0.050$ so it can be concluded that Transformational Leadership has no significant effect on Organizational Citizenship Behavior, an increase in the transformational leadership variable will have an insignificant effect on increasing the Organizational Citizenship Behavior variable and a decrease in the Transformational Leadership variable will have an insignificant effect. to the decrease in Organizational Citizenship Behavior variable. This result is not in line with the research conducted by Sheikh et al. (2018); Tsiotsou et al. (2011); Trihas et al. (2013) that Transformational Leadership has a positive and significant effect on Organizational Citizenship Behavior.

\section{Relationship between Leader Member Exchange and Work Innovation Capabilities}

Based on the results of data analysis using SmartPLS obtained $p$ value of $0.002<0.050$ so it can be concluded that the Leader Member Exchange has a significant effect on Work Innovation Capabilities, an increase in the Leader Member Exchange variable will have a significant effect on increasing the Work Innovation Capabilities variable and a decrease in the Leader Member Exchange variable will have an effect. significant to the decrease in the Work Innovation Capabilities variable. These results are not in line with the research conducted by Affandi et al. (2020), Credo et al. (2010), Zhou et al. (2021), Yunus (2015), Purwanto et al. (2021) that Leader Member Exchange has a positive and significant effect on Work Innovation Capabilities.

\section{Relationship between Leader Member Exchange and Organizational Citizenship Behavior}

Based on the results of data analysis using SmartPLS obtained p value of $0.317<0.050$ so it can be concluded that the Leader Member Exchange has no significant effect on Organizational Citizenship Behavior, an increase in the Leader Member Exchange variable will have an insignificant effect on increasing the Organizational Citizenship Behavior variable and a decrease in the Leader Member Exchange variable will give no significant effect on the decrease in the variable Organizational Citizenship Behavior . These results are not in line with the research conducted by According to Hernández (2020), Kim (2020). E1 Toufaili (2017) that Leader Member Exchange has a positive and significant effect on Organizational Citizenship Behavior.

\section{Relationship between Digital Transformation and Work Innovation Capabilities}

Based on the results of data analysis using SmartPLS obtained $p$ value of $0.335>0.050$ so it can be concluded that Digital Transformation has no significant effect on Work Innovation Capabilities, an increase in the Digital Transformation variable will have an insignificant effect on increasing the Work Innovation Capabilities variable and a decrease in the Digital Transformation variable will have an insignificant effect. 
significant to the decrease in the Work Innovation Capabilities variable. These results are not in line with the research conducted by Yunus (2015), Purwanto et al. (2021), Nugroho et al. (2020), Wijaya et al (2020), Lusiani et al. (2020) that Digital Transformation has a positive and significant effect on Work Innovation Capabilities.

\section{Relationship between Digital Transformation and Organizational Citizenship Behavior}

Based on the results of data analysis using SmartPLS obtained $p$ value $0.335>0.050$ so it can be concluded that Digital Transformation has no significant effect on Organizational Citizenship Behavior, an increase in the Digital Transformation variable will have an insignificant effect on increasing the Organizational Citizenship Behavior variable and a decrease in the Digital Transformation variable will have an insignificant effect. significant to the decrease in the variable Organizational Citizenship Behavior . This result is not in line with the research conducted by Kim (2020). El Toufaili (2017), Fayaz (2017), Quddus (2020) that Digital Transformation has a positive and significant effect on Organizational Citizenship Behavior.

\section{Relationship between Work Innovation Capabilities and Organizational Citizenship Behavior}

Based on the results of data analysis using SmartPLS obtained $p$ value of $0.397>0.050$ so it is concluded that Work Innovation Capabilities have no significant effect on Organizational Citizenship Behavior, an increase in the Work Innovation Capabilities variable will have an insignificant effect on increasing the Organizational Citizenship Behavior variable and a decrease in the Work Innovation Capabilities variable will has no significant effect on the decrease in the variable Organizational Citizenship Behavior . This result is not in line with research conducted by El Toufaili (2017), Fayaz (2017), Quddus (2020) that Work Innovation Capabilities have a positive and significant effect on Organizational Citizenship Behavior.

Table 5. Hypotheses Testing for Undirect Effect

\begin{tabular}{|l|l|l|l|}
\hline Hypotheses & P - Value & Result \\
\hline $\begin{array}{l}\text { Transformational Leadership- Work Innovation Capabilities - } \\
\text { Organizational Citizenship Behaviour }\end{array}$ & 0.584 & Not Significant \\
\hline $\begin{array}{l}\text { Leader Member Exchange -Work Innovation Capabilities - } \\
\text { Organizational Citizenship Behaviour }\end{array}$ & 0.554 & Not Significant \\
\hline $\begin{array}{l}\text { Digital Transformation - Work Innovation Capabilities - Organizational } \\
\text { Citizenship Behaviour }\end{array}$ & 0.545 & Not Significant \\
\hline
\end{tabular}

Relationship between Transformational Leadership and Work Innovation Capabilities through Organizational Citizenship Behavior

Based on the results of data analysis using SmartPLS obtained $p$ value $0.584>0.050$ so it can be concluded that Transformational Leadership has no significant effect on Work Innovation Capabilities through Organizational Citizenship Behavior, an increase in the transformational leadership variable will have an insignificant effect on increasing the Work Innovation Capabilities variable and decreasing the Transformational Leadership variable. will have no significant effect on the decrease in the Work Innovation Capabilities variable through Organizational Citizenship Behavior. This result is not in line with the research conducted by Zhou et al. (2021), Yunus (2015), Purwanto et al. (2021), Nugroho et al. (2020), Wijaya et al (2020), Lusiani et al. (2020) that Transformational Leadership has a positive and significant effect on Work Innovation Capabilities through Organizational Citizenship Behavior.

Relationship between Leader Member Exchange and Work Innovation Capabilities through Organizational Citizenship Behavior

Based on the results of data analysis using SmartPLS obtained $p$ value $0.554>0.050$ so it can be concluded that the Leader Member Exchange has no significant effect on Work Innovation Capabilities through Organizational Citizenship Behavior, an increase in the Leader Member Exchange variable will have an insignificant effect on increasing the Work Innovation Capabilities variable and decreasing the variable. The Leader Member Exchange will have an insignificant effect on the decrease in the Work Innovation Capabilities variable through Organizational Citizenship Behavior. These results are not in line with the research conducted, Purwanto et al. (2021), Nugroho et al. (2020), Wijaya et al (2020), Lusiani et al. (2020) that the Leader Member Exchange has a positive and significant impact on Work Innovation Capabilities through Organizational Citizenship Behavior.

Relationship between Digital Transformation and Work Innovation Capabilities through Organizational Citizenship Behavior

Based on the results of data analysis using SmartPLS obtained $p$ value $0.554>0.050$ so it can be concluded that Digital Transformation has no significant effect on Work Innovation Capabilities through Organizational Citizenship Behavior, an increase in the Digital Transformation variable will have an insignificant effect on 
increasing the Work Innovation Capabilities variable and decreasing the Digital Transformation variable. will have no significant effect on the decrease in the Work Innovation Capabilities variable through Organizational Citizenship Behavior. This result is not in line with research conducted by Fayaz (2017), Quddus (2020) that Digital Transformation has a positive and significant effect on Work Innovation Capabilities through Organizational Citizenship Behavior.

\section{Conclusions}

Based on the results of data analysis, it is concluded that transformational leadership has a significant effect on Work Innovation Capabilities, transformational leadership has no significant effect on Organizational Citizenship Behavior, Leader Member Exchange has a significant effect on Work Innovation Capabilities, Leader Member Exchange has no significant effect on Organizational Citizenship Behavior, digital transformation has no significant effect on Work Innovation Capabilities, digital Transformation has no significant effect on Organizational Citizenship Behavior, Work Innovation Capabilities have no significant effect on Organizational Citizenship Behavior, transformational Leadership has no significant effect on Work Innovation Capabilities through Organizational Citizenship Behavior, Leader Member Exchange has no significant effect on Work Innovation Capabilities via Organizational Citizens hip Behavior, digital transformation has no significant effect on Work Innovation Capabilities through Organizational Citizenship Behavior.

\section{References}

Affandi, A., Sarwani, A. S., Erlangga, H., Siagian, A. O., Purwanto, A., Effendy, A. A., ... \&Juhaeri, G. (2020). Optimization of MSMEs Empowerment in Facing Competition in the Global Market during the COVID-19 Pandemic Time. Systematic Reviews in Pharmacy, 11(11), 1506-1515.

Al Adwan, A., Aladwan, K. M., \& Al-Adwan, A. S. (2019). E-marketing strategic for Jordanian small business to increase sale in local e-market. Academy of Strategic Management Journal, 18(6), 1-13.

Bazazo, I., Alansari, I., Alquraan, H., Alzgaybh, Y., \&Masa'deh, R. E. (2017). The influence of total quality management, market orientation and e-marketing on hotel performance. International Journal of Business Administration, 8(4), 79.

Bui, T. X., Le, T., \& Jones, W. D. (2006). An exploratory case study of hotel e- marketing in Ho Chi Minh City. Thunderbird International Business Review, 48(3), 369-388.

Burawat, P. (2019). The relationships among transformational leadership, sustainable leadership, lean manufacturing and sustainability performance in Thai SMEs manufacturing industry. International Journal of Quality \& Reliability Management.

Chang, H. H., Wang, Y. H., \& Yang, W. Y. (2009). The impact of e-service quality, customer satisfaction and loyalty on e-marketing: Moderating effect of perceived value. Total quality management, 20(4), 423-443.

Cheng, B. L., \& Rashid, M. Z. A. (2013). Service Quality and the Mediating Effect of Corporate Image on the Relationship between Customer Satisfaction and Customer Loyalty in the Malaysian Hotel Industry. Gadjah Mada International Journal of Business, 15(2).

Credo, K. R., Armenakis, A. A., Feild, H. S., \& Young, R. L. (2010). Organizational ethics, leader-member exchange, and organizational support: Relationships with workplace safety. Journal of Leadership \& Organizational Studies, 17(4), 325-334.

Christopher, A. O. (2021). E-marketing and the hotel business promotion: Prospect and challenges in selected hotels in Ado-Ekiti, Nigeria. E3 Journal of Business Management and Economics., 11(1), 020-026.

El Toufaili, B. (2017). The Effects Of Transformational Leadership On Work Innovation Capabilities -A Theoretical Approach. In Proceedings of the International Management Conference (Vol. 11, No. 1, pp. 153-163).

El-Gohary, H. (Ed.). (2013). E-Marketing in Developed and Developing Countries: Emerging Practices: Emerging Practices. IGI Global.

Fayaz, M., \& Shah, S. A. (2017). Relationship between entrepreneurial orientation and firm performance: Moderation of transformational leadership in the context of Pakistani SMEs. Journal of Managerial Sciences, 11(4), 405-420.

Quddus, A., Nugroho, B. S., Hakim, L., Ritaudin, M. S., Nurhasanah, E., Suarsa, A., ... \&Sudargini, Y. (2020). Effect of Ecological, Servant dan Digital Leadership Style Influence University Performance? Evidence from Indonesian Universities. Systematic Reviews in Pharmacy, 11(10), 408-417.

Fernandes Sampaio, C. A., Hernández Mogollón, J. M., \& de Ascensão Gouveia Rodrigues, R. J. (2020). The relationship between market orientation, customer loyalty and business performance: A sample from the Western Europe hotel industry. Tourism and Hospitality Research, 20(2), 131-143. 
Gandolfi, F., \& Stone, S. (2018). Leadership, leadership styles, and Leader Member Exchange. Journal of Management Research, 18(4), 261-269.

Gui, L., Lei, H., \& Le, P. B. (2021). Determinants of radical and incremental innovation: the influence of transformational leadership, knowledge sharing and knowledge-centered culture. European Journal of Innovation Management.

Hernández-Perlines, F., \& Araya-Castillo, L. A. (2020). Leader Member Exchange, innovative capacity and performance in third sector entities. Frontiers in psychology, 11, 290.

Hua, N., Hight, S., Wei, W., Ozturk, A. B., Zhao, X. R., Nusair, K., \&DeFranco, A. (2019). The power of ecommerce: Does e-commerce enhance the impact of loyalty programs on hotel operating performance? International Journal of Contemporary Hospitality Management.

Iddris, F., \& Ibrahim, M. (2015). Examining the relationships between e-Marketing adoption and Marketing Performance of Small and Medium Enterprises in Ghana. Journal of Marketing and Consumer Research, 10, 160-169.

Kandampully, J., \&Suhartanto, D. (2000). Customer loyalty in the hotel industry: the role of customer satisfaction and image. International journal of contemporary hospitality management.

Kim, E. J., \& Park, S. (2020). Transformational leadership, knowledge sharing, organizational climate and learning: an empirical study. Leadership \& organization development journal.

Labanauskaitè, D., Fiore, M., \&Stašys, R. (2020). Use of E-marketing tools as communication management in the tourism industry. Tourism Management Perspectives, 34, 100652.

Lim, W. M. (2010). Factor analysis of variables affecting e-marketing adoption by UK independent hotels. In Information and Communication Technologies in Tourism 2010 (pp. 39-50). Springer, Vienna.

Lončarić, D., \&Radetić, N. (2015). The implementation of e-marketing in the hotel industry: The case of Istria county. ZbornikVeleučilišta u Rijeci, 3(1), 12-24.

Lusiani, M., Abidin, Z., Fitrianingsih, D., Yusnita, E., Adiwinata, D., Rachmaniah, D., ... \& Purwanto, A. (2020). Effect of Servant, Digital and Green Leadership toward Business Performance: Evidence from Indonesian Manufacturing. Systematic Reviews in Pharmacy, 11.

Maroukian, K., \& Gulliver, S. R. (2020, ). The link between transformational and Leader Member Exchange in DevOps-oriented organizations. In Proceedings of the 2020 European Symposium on Software Engineering (pp. 21-29).

Mousavi, S. S. (2012). Effective Elements on E-Marketing strategy in Tourism Industry (Case study: Airlines, Tour Operator and Chain Hotels in Germany and Iran).

Nasihatkon, B., Kheiri, J., \&Miralbell, O. (2016). Social media and hotel e-marketing in Iran: The case of Parsian International Hotels. Turyzm/Tourism, 26(2), 15-21.

Novitasari, D., Haque, M. G., Supriatna, H., Asbari, M., \& Purwanto, A. (2021). Understanding the Links between Charismatic Leadership, Intrinsic Motivation and Tacit Knowledge Sharing among MSME Employees. International Journal of Social and Management Studies, 2(3), 1-13.

Peštek, A., \&Cicic, M. (2010). Application of e-marketing strategies in tourism sector in Bosnia and Herzegovina. In Proceedings, 5th International Conference "An Enterprise Odyssey: From Crisis to Prosperity-Challenges for Government and Business (pp. 132-145).

Purwanto, A., Purba, J. T., Bernarto, I., \&Sijabat, R. (2021). The Role of Transformational Leadership, Organizational Citizenship Behaviour, Innovative Work Behaviour, Quality Work Life, Digital Transformation and Leader Member Exchange on Universities Performance. LinguisticaAntverpiensia, 2908-2932.

Purwanto, A., Purba, J. T., Bernarto, I., \&Sijabat, R. (2021). Peran Organizational Citizenship Behavior (OCB), Transformational and Digital Leadership Terhadap Kinerja MelaluiMediasiKomitmenOrganisasi Pada Family Business. JENIUS (JurnalIlmiahManajemenSumberDayaManusia), 4(3), 256-272.

Purwanto, A. (2021). Partial Least Squares Structural Squation Modeling (PLS-SEM) Analysis for Social and Management Research : A Literature Review. Journal of Industrial Engineering \& Management Research, 2(4), 114 - 123. https://doi.org/10.7777/jiemar.v2i4.168

Purwanto, A., Asbari, M., \& Santoso, T. (2021). Education Management Research Data Analysis: Comparison of Results between Lisrel, Tetrad, GSCA, Amos, SmartPLS, WarpPLS, and SPSS For Small Samples. NidhomulHaq : JurnalManajemen Pendidikan Islam, 6(2), 382-399. https://doi.org/10.31538/ndh.v6i2.1575

Purwanto, A., Asbari, M., \& Santoso, P. B. (2019). Does Culture, Motivation, Competence, Leadership, Commitment Influence Quality Performance?. Inovbiz: JurnalInovasiBisnis, 7(2), 201-205.

Purwanto, MasdukiAsbari,Teguh Iman Santoso, VipParamartaDenokSunarsi (2021).Social and Management Research Quantitative Analysis for Medium Sample: Comparing of Lisrel, Tetrad, GSCA, Amos, SmartPLS, WarpPLS, and SPSS.JurnalllmiahIlmuAdministrasiPublik: JurnalPemikiran dan PenelitianAdministrasi Publik.9(2).518-532 
Purwanto,MasdukiAsbari,Teguh Iman Santoso,Marissa Grace Haque,Nurjaya (2021)Marketing Research Quantitative Analysis for Large Sample: Comparing of Lisrel, Tetrad, GSCA, Amos, SmartPLS, WarpPLS, and SPSS.JurnalIlmiahIlmuAdministrasiPublik: JurnalPemikiran dan PenelitianAdministrasi Publik.9(2).355-372

Purwanto, A., Asbari, M., Santoso, T. I., Sunarsi, D., \& Ilham, D. (2021). Education Research Quantitative Analysis for Little Respondents: Comparing of Lisrel, Tetrad, GSCA, Amos, SmartPLS, WarpPLS, and SPSS. JurnalStudi Guru Dan Pembelajaran, 4(2), 335-348. https://doi.org/10.30605/jsgp.4.2.2021.1326

Purwanto, A., Asbari, M., \& Santoso, T. I. (2021). Analisis Data PenelitianSosial dan Manajemen: Perbandingan Hasil antara Amos, SmartPLS, WarpPLS, dan SPSS UntukJumlahSampel Medium. International Journal of Social and Management Studies, 2(4), $43-53$. https://doi.org/10.5555/ijosmas.v2i4.50

Purwanto, A., Asbari, M., \& Santoso, T. I. (2021). Analisis Data Penelitian Marketing: Perbandingan Hasil antara Amos, SmartPLS, WarpPLS, dan SPSS UntukJumlahSampelBesar. Journal of Industrial Engineering \& Management Research, 2(4), 216 - 227. https://doi.org/10.7777/jiemar.v2i4.178

Purwanto, A., Asbari, M., \&Santosi, T. I. (2021). Analisis Data PenelitianManajemen Pendidikan: Perbandingan Hasil antara Amos, SmartPLS, WarpPLS, dan SPSS UntukJumlahSampel Kecil. International Journal Of Social, Policy And Law, 1(1), 111 - 121. https://doi.org/10.8888/ijospl.v1i1.64

Rather, R. A., \& Sharma, J. (2017). The effects of customer satisfaction and commitment on customer loyalty: Evidence from the hotel industry. JOHAR, 12(2), 41.

Salem, I. E. B., El-Said, O. A., \& Nabil, M. (2013). Determinants and effects of applying electronic marketing in Alexandria hotels: Current status and future trends. Journal of Tourism and Hospitality, 2(2), 112.

Siakalli, M., Masouras, A., \&Papademetriou, C. (2017). e-Marketing in the hotel industry: marketing mix strategies. In Strategic Innovative Marketing (pp. 123-129). Springer, Cham.

Singh, A. S. H. O. K., \& Rathore, D. S. (2018). Customers' satisfaction with E-Marketing Tools used by Budget Hotels of Udaipur. South Asian Journal of Tourism \& Heritage, 18(2).

Sheikh, A. A., Rana, N. A., Inam, A., Shahzad, A., \& Awan, H. M. (2018). Is e-marketing a source of sustainable business performance? Predicting the role of top management support with various interaction factors. Cogent Business \& Management, 5(1), 1516487.

Tsiotsou, R. H., \&Vlachopoulou, M. (2011). Understanding the effects of market orientation and e- marketing on service performance. Marketing Intelligence \& Planning.

Trihas, N., Mastorakis, G., Perakakis, E., \&Kopanakis, I. (2013). Efficient e-marketing in tourism through a novel customer relationship management model. GSTF Journal on Business Review (GBR), 3(1), 1-6.

Zhou, X., Rasool, S. F., Yang, J., \& Asghar, M. Z. (2021). Exploring the Relationship between Despotic Leadership and Job Satisfaction: The Role of Self Efficacy and Leader-Member Exchange. International Journal of Environmental Research and Public Health, 18(10), 5307.

Yunus, N. H., \& Ibrahim, W. N. (2015). Employees' Organizational Commitment: The Effect of Leaders' Transformational Leadership and Leader-Member Exchange as Moderator. International Journal of Art and Commerce, 4(2), 123-135.

Nugroho, B. S., Suheri, S., \& Hakim, L. (2020). Effect of Knowledge Sharing dan Leader member Exchange (LMX) and Organizational Citizenship Behavior (OCB) to Indonesian Lectures' Performance. Systematic Reviews in Pharmacy, 11(9), 972-981.

Wijaya, A. P., Bernarto, I., \& Purwanto, A. (2020). How to achieve value creation in digital world? the influence of IT response on value creation and customer satisfaction. 